\title{
MANAGING THE CONSEQUENCES OF THE FRAGMENTATION OF RELIGIOUS AUTHORITY: LESSONS LEARNED FROM MALAYSIA AND SINGAPORE
}

\author{
Fazlul Rahman \\ Institut Agama Islam Syarifuddin \\ Lumajang, East Java \\ fazlulrahman85@gmail.com
}

\begin{abstract}
Media infiltration in the Indonesian Muslim community has made the existence of religious authority increasingly fragmented. This fragmentation eventually gave birth to some serious consequences: loss of control to religious symbols, overlapping truth claims and relativization of religious authority. Several recent cases, starting from the mushrooming of Muslim celeb-clerics, cases of criminalization of ulama, bullying the figures of senior ulama on social media, to the politicization of ulama identities in elections, are clear tokens of the consequences. The question is how to manage those consequences of the fragmentation of religious authority? This paper discusses the problem based on a comparative analysis of the data collected during fieldwork in Malaysia and Singapore in 2018. The data was collected by interviewing imams, asatizah, and university professors in both countries as well as Indonesian professors and the grand imam of the Istiqlal Mosque as the complementary. Using the mediatization theory as its theoretical basis, this research found that there are several important arguments to deal with the consequences. As a concluding remark, this paper proposes a formula of maqāsid -based media ethics as an alternative point of view of an ethical construction of Muslim society's interaction with media.
\end{abstract}


[nfiltrasi media telah menimbulkan fragmentasi dalam tubuh otoritas keagamaan Islam Indonesia. Hal tersebut melahirkan beberapa konsekuensi, seperti hilangnya kontrol terhadap simbolsimbol agama, tumpang tindih klaim kebenaran, dan relativisasi otoritas keagamaan. Beberapa kasus yang muncul akhir-akhir ini, seperti hadirnya fenomena ustad-seleb, kriminalisasi ulama, pembully-an ulama terhormat di sosial media, hingga politisasi identitas ulama dalam pemilihan umum adalah contoh nyata dari konsekuensi tersebut. Pertanyaan mendasarnya adalah: bagaimana cara menata konsekuensi-konsekuensi itu? Berbasis data penelitian yang dikumpulkan di Malaysia dan Singapura pada tahun 2018, artikel ini berupaya mendiskusikannya melalui pendekatan komparatif. Data-data dalam artikel ini diperoleh melalui wawancara dengan para imam masjid, ustad, dan beberapa dosen di dua negara, ditambah dengan wawancara khusus dengan imam besar masjid Istiqlal dan beberapa dosen. Menggunakan teori pemedia-an (mediatization theory) sebagai landasannya, penelitian ini menemukan beberapa argumen penting terkait konsekuensikonsekuensi di atas. Sebagai penutup, artikel ini menawarkan apa yang disebut sebagai etika media berbasis maqāșid sebagai poin alternatif dan struktur etis dalam membangun interaksi antara masyarakat Muslim dengan media.]

Keywords: media, religious authority, ulama, Malaysia, and Singapore

\section{Introduction}

Hoover sees that when the media are becoming more important in society, there are clear implications for religious authority. He wrote that "the media today directly confront religious authorities' ability to control their own symbols and symbolic resources."1 Before the coming of the internet, religious authority belongs to one particular class, the ulama. When the internet comes, it changes the picture of religious authority which

\footnotetext{
${ }^{1}$ Stewart M. Hoover (ed.), The Media and Religious Authority (Pennsylvania: The Pennsylvania State University Press, 2016), 5.
} 
is no more exclusively owned by the ulama class. Like the characteristics of a rhizome, it is now multiplied, connected, and heterogeneous. ${ }^{2}$

One clear problem of the aforementioned consequences of the rhizomatic fragmentation of religious authority, in general, is the problem of management. There should be a more sophisticated way to control and manage the situation. The reconfiguration of the religious authority's structure needs an urgent effort to rejuvenate the way by which we control the fragmentation. Hoaxes, rises of online or offline 'pseudo-ulama', and inter-religious conflicts caused by misunderstanding of religious discourses are the current examples of social problems relating to the critical fragmentation of religious authority.

This paper discusses the problem of socio-religious impacts of the fragmentation of religious authority based on the data collected during a field-work in Malaysia and Singapore in 2018. The data was collected by interviewing imams, asatizah, and university professors in both countries as well as Indonesian professors and the Grand Imam of the Istiqlal Mosque.

\section{Media and Religion in Malaysia and Singapore}

This subsection will explore the current usage of media related to religion in two different countries, Malaysia and Singapore. Here, this paper will not dig deeper into how the constitutional law limits the usage of media for religion but more on the exploration of the position of religion in both countries' media.

\section{A. Muslim-Only Media Usage in Malaysia}

As a matter of fact, the governance of Malaysia practices Parliamentary Democracy with a constitutional monarch, His Majesty the Yang di-Pertuan Agong, as the Supreme Head of the country. In keeping with the concept of Parliamentary Democracy

\footnotetext{
2 Gilles Deleuze and Félix Guattari, A Thousand Plateaus: Capitalism and Schirophrenia (Minneapolis: University of Minnesota Press, 1987), 7-8.
} 
which forms the basis of the government administration in Malaysia, the Federal Constitution underlines the separation of governing powers among the Executive, Judicial and Legislative Authorities. The separation of power occurs both at the Federal and State level. Media at this point is governed under the central government or the federal territories, not the states. However, the state ruler, the sultan, has the authority to take action against deviant religious activities that occur in media like the viral case of a preacher offended Sultan of Johor on the issue of Muslim-only launderette. ${ }^{3}$

To regulate the usage of media in Malaysia, there are some laws has been issued. Among them: (1) Printing Presses and Publications Act 1984; (2) Digital Signature Act 1997, (3) Computer Crimes Act 1997, (4) Telemedicine Act 1997; (5) Communications and Multimedia Act 1998; and (6) The Malaysian Communications and Multimedia Content Code.

With those laws on media in Malaysia, there was a rising concern on the media freedom in the country and its limitations. This research would like to underline from those laws on different media that the use of media for religious propagation or promotion in TV, radio, internet articles are legally allowed, as long as it is propagation for Islam. In consequence, any religions other than Islam are not allowed to be publicly promoted. Not even in media platforms. That is according to article 11 (4) of the Federal Constitution which states clearly that the propagation of non-Islamic religions among Muslims is forbidden.

There are at least three justifications for that prohibition. The first relates to the special status and position of Islam in Malaysia from its very beginning. The second relates to the key role of Malay Rulers in preserving the sanctity of the Islamic

\footnotetext{
3 Shannon Teoh, "Malaysian Preacher Arrested for Sedition after Criticizing Johor Sultan's Decree against Muslim-Only Launderette," The Straits Times, last modified October 11, 2017, accessed December 27, 2018, https://www.straitstimes.com/asia/se-asia/malaysian-preacher-apologises-overcomments-criticising-johor-sultans-decree-against.
} 
religion from the pre-independence period until the present, and the third justification relates to the nature of Islamic teachings and the maxim that apostasy is a crime. ${ }^{4}$ Accordingly, as it is clearly mentioned by Mr. Azam Adil (The Deputy CEO of the International Institute of Advanced Islamic Studies Malaysia), Malaysian Muslims can live in peace and harmony with different races, different religions but other Muslims cannot propagate their religions to them. Even if that propagation has been done through media, still will be considered as against the law.

Another interesting case of the usage of media for religious purposes in Malaysia is the usage of screen and PowerPoint during Jum'ah prayer. Most of the mosques I visited in Malaysia nowadays equipped with a TV screen that used to show information about the mosques' activities, salah times, and some short religious teachings from the Quran and hadith. This new initiative of using multimedia for khutbah was introduced first on February $3^{\text {rd }}, 2006$ in Masjid al-Muktafi Billah Shah, Trengganu which then by Federal Territory Islamic Affairs Department (JAWI) in January 2007.

Siti Aishah in her dissertation found that "Khutbah Juma'at Multimedia" is aimed to increase interest and understanding among Muslims with the aid of technological devices (Aishah, 2012). Khutbah's slide was all prepared by the JAWI and what the khatib should do is only delivering what they got from the slides. With regard to our discussion on religious authority, I do agree with Samuri and Hopkins who argue that kind of weekly Friday khutbas have been used to announce the Islamic authorities' commitment to safeguarding the sanctity, to monopolize the interpretation of Islam, to establish the collective mainstream of

\footnotetext{
4 Zuliza Mohd Kusrin, et al., "Legal Provisions and Restrictions on The Propagation of Non-Islamic Religions Among Muslims in Malaysia," Kajian Malaysia 31, no. 2 (2013): 1-8.
} 
minority Muslims groups, and to promote the implementation of budud law. ${ }^{5}$

The last interesting fact found in the field is the usage of the Internet for religious purposes. In 2018 The Department of Statistics Malaysia published a press release on ICT use and access by individuals and households survey report, Malaysia 2017. It says that the internet used by individuals in 2015 was $71.1 \%$ and it becomes $80.1 \%$ in 2017 . In other words, there is the staggering growth of Internet users in Malaysia by increasing $880 \%$ from 2006 until 2017. ${ }^{6}$ With regard to this growth, it is interesting to find that "Muslims who exhibited greater offline media usage for religious purposes, such as seeking Islamic information through print, television, radio and interpersonal channels, displayed greater participation at online religious environments." ${ }^{\prime 7}$ This goes in line with the opinion of the most imams I interviewed when they were asked how to handle the negative impact of the internet, they see that the first thing to do is to build a strong religiouscommitted family. They believe that individuals who raised in a good family's environment will consistently show good attitudes outside family life including in the matters of religious life.

\section{B. Media Usage for Religion in Singapore}

Information and communication technologies (ICT) is one of the pillars of Singapore's economic success. The higher the value of ICT indicators as in the case of Singapore, Brunei, and Malaysia, the lower the poverty rank. However, Singapore's mass

\footnotetext{
5 Mohd Al Adib Samuri and Peter Hopkins, "Voices of Islamic Authorities: Friday Khutba in Malaysian Mosques," Islam and Christian-Muslim Relations, 28, no. 1 (January 2, 2017): 47-67.

${ }^{6}$ Adib Povera, "Internet Users in Malaysia up from 2.5mil in 2006 to $24.5 \mathrm{mil}$ in 2017," New Straits Times, (accessed December 26, 2018). Read https://www.nst.com.my/news/nation/2018/02/331284/internet-usersmalaysia-25mil-2006-245mil-2017.

7 Azimaton Abdul Rahman, Nor Hazlina Hashim, and Hasrina Mustafa, "Muslims in Cyberspace: Exploring Factors Influencing Online Religious Engagements in Malaysia," Media Asia 42, no. 1-2 (April 3, 2015): 61-73.
} 
communications networks, including television and phone networks, have long been operated by the government. In terms of news broadcasting, the government holds tight control over all news in Singapore. Beginning in 1968 officials assumed oversight of print media under the authority of the Newspapers and Printing Presses Act (NPPA). This legislation allows the government to "restrict the sales of publications that persistently indulge in slanted reporting and distortions of facts."

Media regulation in the Republic of Singapore is under the responsibility of Info-communications Media Development Authority (IMDA), a statutory board in the Singapore government that "seeks to deepen regulatory capabilities for a converged infocommunication media sector, safeguarding the interests of consumers and fostering pro-enterprise regulations." There are various media regulations that related to the IMDA's authority. First is the info-communications Media Development Authority Act that establishes the IMDA, to provide for its functions and powers, and for matters connected therewith. Second is the Broadcasting Act (Cap. 28) which regulates the operation of and ownership in broadcasting services and broadcasting apparatus. The third is The Electronic Transactions Act that covers matters such as electronic records, signatures and contracts and other matters. Forth is the Films Act (Cap. 107) relating to the possession, importation, making, distribution and exhibition of films. The fifth is the Newspaper and Printing Presses Act (Cap. 206) for the licensing of newspaper companies and for matters connected therewith. Sixth is the Personal Data Protection Act that governs the collection, use, disclosure and protection of personal data by organizations. Seventh is the Postal Services Act (Cap. 237A) that covers matters such as the licensing of postal services for the conveyance of letters, postal services and systems, and other matters. Eighth is the Public Entertainments Act (Cap. 257) that provides for the regulation of public entertainments and meetings. Ninth is the Telecommunications Act (Cap. 323) that 
relates to the licensing of telecom systems and services and grant of spectrum rights, among other matters. The tenth is the Undesirable Publications Act (Cap. 338) which prevents the importation, distribution or reproduction of undesirable publications and for purposes connected therewith.

Among those media regulations, only two of them touch the issue of religion and both are not related to media. Here this paper will not go further discussing the media regulation, instead, it will focus more on the realities of the media usage for religion. At that point, it is interesting to find that the fundamental conception of the usage of new media technology by those who are affiliated to a particular religion is the notion that it functions more as a participatory and corrective tool for these informants to counter what they perceive as "stereotypical depictions" of their faiths by mainstream media. The new-media technology facilitated them to be able to rethink their understanding of religion and correct the gap in mainstream media about their religion. ${ }^{8}$ With regard to our discussion on religious authority in a media environment, Feng and Chen found that the nature of new media that eliminates icons in mediating religious content has created an equal change for anyone who engages in new media to represents and be the "spokespersons" for their particular religion. That creates a high possibility of lay people to become an "instantreligious iconic figure."

Even though the National Survey by The Singapore Internet Research Centre in 2004 found that Singaporeans were much likely to use the internet to engage in activities related to their own religion than to other religions, suggesting that the internet does not necessarily lead to an understanding of other

8 Robin Chee Ming Feng and James Chen, "Shopping for God: Media and Religion In Singapore," in Francis Khek Gee Lim (ed.), Mediating Piety (London: Brill, 2010), accessed December 30, 2018, https://brill.com/view/book/edcoll/9789047440741/Bej.9789004178397.i240_009.xml.

${ }^{9}$ Ibid., 170-171. 
faiths, ${ }^{10}$ but still, people get benefit from the media's facility to provide information regarding the outsiders' opinions and attitudes towards their religion. That felt practically useful for the context of maintaining religious harmony in Singapore. While the government, in the name of religious harmony, restricts reports and write-ups that might ignite religious debates from surfacing the major media in the nation, Feng and Chen found that new media tools can provide alternative channels to understand outsiders' attitudes toward their religion. ${ }^{11}$

Another important fact found in the field related to media usage for religious purposes is the Singaporean imams' perspective on media and their decision to use or not to use media. According to my interview with nine official imams in Singapore, there are at least four important points I would like to underline.

First, the general perception of the imams related to media, be it old or new media, is that media nowadays becomes an undeniable part of our everyday lives, including the life of the imams. Besides its function as a communication tool for familial or business purposes, the media, the imams admitted, very much helpful in providing diverse information about religion. This finding confirms previous research's finding on technological modernization, the internet, and religion in Singapore that reveals, based on an interview with religious leaders of a diverse set of faiths of Singapore, a broad acceptance of the Internet and other information technologies and a little sense of a danger to religious faith. ${ }^{12}$

\footnotetext{
${ }^{10}$ Randolph Kluver, et al., "The Internet and Religion in Singapore: A National Survey," (Singapore: Singapore Internet Research Center, 2005).

11 Robin Chee Ming Feng and James Chen, "Shopping For God: Media and Religion in Singapore," in Francis Khek Gee Lim, Mediating Piety (London: Brill, 2010), 172.

12 Randolph Kluver and Pauline Hope Cheong, "Technological Modernization, the Internet, and Religion in Singapore," Journal of Computer-Mediated Communication, 12, no. 3 (April 2007): 1122-1142.
} 
However, all of the informants remind us to stay active and wise in using the media, in filtering information we got from media and not to distract us from fundamental religious obligations like prayers and remembering God. At this point, it is interesting to find one imam admittedly had decided not to use social media for the last two years, only the WhatsApp Application. According to him, social media has caused negative attitudes to its users, like losing a good manner (adab). As there is no strict religious-regulation inside social media, people usually act with no attention to Islamic akblaq inside it. With many features of self-exposure facilitated by the social media environment, the imam sees that it will lead us to do everything not sincerely for God. In conclusion, the imam encourages Muslims to avoid social media as there are so many fitnas nowadays.

With regard to religious information, I found one imam who strongly encourages not to refer to the internet in finding religious information. The imam himself prefers to go to the main sources from kitab to find and understand Islamic teachings. Even one of my key informants for this research, who is a doctor in Inter-religious studies, was appointed as official imam and currently being activist of inter-religious dialogue, clearly admitted that.

Googling needs to be controlled by a syaikh, a real person. That real person must be a teacher who guides you. We are advocating that. We are sounding that, we are amplifying that. Telling everybody this is dangerous. Because I am also an RRG member. RRG is the Religious Rehabilitation Group. We do rehab detainees terrorism. So once a month a would do counseling for these people. Where they are in prison right now. Most of them are in this case self-radicalized. How? When they learn something that they like to see. Jihad and the want to go. So these are all dangerous actually, very dangerous. And it is known. We are propagating it. ${ }^{13}$

${ }^{13}$ Interview with Leyaket Ali, (November 9, 2018). 
Second, most of the mosques in Singapore are "heavily mediated." The Friday Kbutba in most of the mosques is equipped by LCD Screens projecting slides of presentations. We will find the official websites of the mosques in Singapore informing their activities, history of the mosques, and some short explanations of religious teachings. For big mosques, as it is supported by MUIS, they usually have a particular live streaming program contains khutba, religious sermons, or mosques' activities. I found the government limits access to religious organizations that officially not recognized in Singapore like the Ahmadi. In this context, I once experienced difficulty finding the location of Taha Mosque, the only mosque for the Ahmadi Muslim Community in the country, as the Google Maps give no information or direction to its location.

Third, I found from the interviews a clear impression from the imams of being surveilled by the government. This especially shown by their attitude when they were asked about particular controversial religious issues. Most of the imams choose not to give a response and encourage me to find the answer in MUIS website instead. Another evidence of the imams' feeling of being surveilled is when they were asked if they have critics of any of MUIS' policies or regulations. Most of the imams, apparently, were have no comment on that question.

Fourth, there is a general perception among the imams regarding the positive impact of strict regulation on religious life in Singapore, including the one in media life. Most of the imams praise the government for having strict control to the country especially with regard to religious life as that control make Singapore the safest place, no deviant religious teachings will easily come to the country, religious harmony peacefully maintained, and Muslims can focus on upgrading their religious and worldly life. 


\section{Media and Fragmentation of Religious Authority: Managing the Consequences}

The following discussion intended to explore specifically the effect of the presence of the media on religious authorities in those two countries, especially in the case of fragmentation of religious authorities caused by the media and how to manage its consequences. According to Hoover, there are at least three obvious consequences from the appearance of the media towards religious authorities: loss of control to religious symbols, overlapping truth claims, relativization of religious authority. ${ }^{14}$ The discussion in this sub-section will shed light on how to control those consequences which based on my interview with the scholars and imams

\section{A. Loss of Control to Religious Symbols}

To begin with, it is interesting to bring up Nasarudin Umar's (the Grand Imam of Istiqlal Mosque) argument when he was asked that with the arrival of the media, religion had lost control of its symbols because the media easily forced religious symbols to any direction. He replied:

That's an unfair assessment of the media. You must be sure that without the media, religious teachings, especially Islam, will not become as big as now. So, we must thank the media. Without the media, Islam will not be like it is now. 15

A different perspective comes from Mustain Mashud, a professor of sociology at Airlangga University, who argues that it has happened and that will never return to normal. According to him, the public or the community nowadays is so differentiated. They become scattered organs. People with all their abilities to access

\footnotetext{
${ }^{14}$ Stewart M Hoover, The Media and Religious Authority (US: Pennsylvania State University Press, 2017).

${ }^{15}$ Interview with Nasarudin Umar, (December 2018).
} 
news and information from anywhere every day. So, to bring them back to previous religious life patterns is something impossible. At the same time, the individual needs of the economy, in particular, are increasing and diverse. While the source of life becomes increasingly competitive. So those people will definitely get higher levels of competition. As a result, people want to show their existence using various things, especially religion. Particularly, religious symbols. Islam, at this point, is the easiest, the most vulnerable to be used. Because while using religion, people talk a lot about emotions rather than rationality. He further argues that the only way to manage this mess is education. ${ }^{16}$

Going in the same vein, Osman Bakar, distinguished professor and Al-Ghazali Chair of Epistemology and Civilizational Studies and Renewal at ISTAC Malaysia, argues that it happens. The media does not know the limits. To solve this problem, he basically suggests that:

The media should respect... yea, should have freedom. But the freedom of the media should not be to the extent of disruptive... disrupting society.

It is just a matter of how we give proper understanding to the public about the symbols of Islam. When one of the symbols is abused, whoever there is will definitely be a reaction. Because the symbol for me personally is my belonging. But we as religious leaders, are demanded how the community is given a correct understanding of religious symbols. So, will not easily be provoked. ${ }^{17}$

\section{B. Overlapping Truth Claims}

Another obvious impact of media on the religious authority is in a way that media opens a wide space to truth claims.

\footnotetext{
${ }^{16}$ Interview with Musta'in Mashud, (December 1, 2018).

${ }^{17}$ Interview with Osman Bakar, (December 2018).
} 
Commenting on this, Nasarudin reminds us to see the problem from the positive side.

But I see the media more from the positive side. Without media, there will no development, no civilization, no progress. The media is what makes the achievements of human culture more powerful. Try to imagine without media. So, let's thank the media. Don't lament the presence of the media... The most important thing is the fact that the problem is not the media, but the morality of those who hold the media that needs to be resolved. But if there is no piety, that will be not the case. So, don't judge the media just because of the emergence of a lot of turmoil in society. I don't agree with that. The media must be grateful. Without the media, human dignity will not be upheld .... So, the media is upgrading human rights, women's rights, children's rights, even animal rights, plant rights, natural rights, and human rights. So, the media arouses love for all of God's creatures. ${ }^{18}$

Another simple and straight important argument on how to handle the overlapping truth claims in media comes from Mashud who said that the only way to handle is to counter with media itself. unfortunately, and this is the main weakness of Muslims is, that they do not have and do not master the media. He reminds us:

We can't do it in our own way. Like by doing Istighasah for example. Even though it doesn't solve the problem. I mean, yeah, we pray, we do istighasah, it's okay. But it has to be done by a plan, by design, which is measurable. Don't forget that in the future the community will become more rational. Well, I don't want the religious leaders to hegemony the

${ }^{18}$ Interview with Nasarudin Umar, (December 2018). 
congregation just for the continuity of the structure. It is dangerous. ${ }^{19}$

A more concrete work related to media counter by Muslims might be explained by Ushama, professor of Islamic Philosophy at IIUM Malaysia, argument:

To me, Muslim countries have this information ministry. Every country has a ministry of information that controls electronic media, print media, social media, and all. That ministry should have the proper vision of promoting the Islamic philosophy of life, the Islamic world view, and Islamic civilization. So, they must be able to evaluate who should be given a slot and who should not be given a slot. But, again, it should be objectively done... and It can be objective if it is properly trained, if it is properly monitored, checked, and the training is given by the Muslim journalist. ${ }^{20}$

The overlapping claims of truth is indeed a serious problem. It should be must be handled with mutual assistance by all elements of society and the government. As it is argued by Bakar:

This is in fact, even the government itself is not in the position... No, by itself. If the government alone by themselves they can solve this problem, then they are dreaming. No, they cannot. But of course, the government plays a very important role. But also, the civil society. Well, what civil society can do is present to point out, in terms of the relationship between a state and civil society, the role of civil society, number one, is to point out the scope of authority, not to transgress, not to go. Again, it's the limits of their legitimate

\footnotetext{
${ }^{19}$ Interview with Musta'in Mashud, (December 1, 2018).

${ }^{20}$ Interview with Ushama, (December 2018).
} 
authority. They don't have that absolute authority.

Because the authority belongs to the people. ${ }^{21}$

Related to the role of civil society to overcome the problem, learning from what MUIS did with the ARS, one of the Singaporean imam suggests that the big Muslim religious organization in Indonesia, like Muhammadiyah and NU should issue a guideline that can be used as a reference for society how to deal with media. Those guidelines might also be supported by law and made it mandatory as official constitutional law. ${ }^{22}$

\section{Relativization of Religious Authority}

The last obvious impact of media on religious authority is that media makes it becomes more relative which ultimately gave room for the emergence of pseudo-scholars. Responding to this, Mashud clearly confirms this:

Yes, for sure. That is now clear. Now we found many ulama, many kiai, many new ustar arise together with the media. It is not the same with da'wah before, it is kind of media information that penetrate geographical barriers, cultural barriers, political barriers, any kind of barriers. That's amazing. ${ }^{23}$

Following that, the more important thing is how to then control this phenomenon? According to him, there is nothing can control this except the public. Also, he reminds us that for religious authority to stand still, it needs to have an offline existence. Because, one Singaporean imam argues that most of the time, how great the authority someone has in a media environment is not necessarily the same thing when it comes to the real environment. Here, Mashud explicitly argues:

${ }^{21}$ Interview with Osman Bakar, (December 2018).

${ }^{22}$ Interview with Ust. Rahmani, (December 4, 2018).

${ }^{23}$ Interview with Musta'in Mashud, (December 1, 2018). 
Who can control? Public, finally the Public. So, now nobody controls it actually. Just see, what controls? What? Nothing. It is viral for less than a month and then it's gone. Just gone. Because he doesn't have a foundation in the offline world. Well, what I want to say is. People often feel great, feel modern, feel extraordinary because of the media, because they are modern. "Well, you should remember that you are even more helpless." The more modern, the more helpless. "Your life, your school, your information are coming from a gadget." Then what happens when the gadget is turned off. We use Telkomsel, for example, now it's just had overnight trouble. It confuses people. $^{24}$

From the above interview, I do agree that the public holds a great responsibility to control this critical phenomenon. However, the religious leaders, at this point play even a more important role. they must be in the front row guarding this problem. Of course, together with the government. One Singaporean imam said:

We are here in Singapore, or indeed in any country, we cannot / will not be able to block the media. People talk in the media. Only, it finally will go back to the religious leaders in the community to guide them. Those are who should play their role. The religious leaders must play their role. And not enough, there must be support from the government. Government support is needed. So, the (last) guard is the government. ${ }^{25}$

Besides control from the public, religious leaders, and the government, Yusof reminded us of the importance of good management in doing that. Like formulating together a universal guideline on how to strengthen the existence of religious authority in such a media life.

\footnotetext{
${ }^{24}$ Ibid.

${ }^{25}$ Interview with Singaporean Imam, (December 2018).
} 
Other than those aforementioned factors, there are other important factors and suggestions on how to manage the consequences of the fragmentation of religious authority. First, education. One of Malaysian imam argues that "Education problem. If parents also have high education, the community or the people have high education, small things (like media), they will not become an issue." 26

In the context of education, another Malaysian imam suggests specifically the importance of instilling reading culture for the young generation. This positive culture will help them to avoid consuming religious information instantly so they can understand religion better and get inspired.

The need for upgrading society's educational level should also continue to be encouraged among the imam or da'is, in a systematic and continuous basis. That might be in the form of regular meeting and training with the direction from the central government, such as the minister of religion or grand mufti. Where the da'is can share and upgrade their knowledge related to religious matters and, even more, can have the same vision and hearth. ${ }^{27}$

The second important factor to face the impact of media on religious authority is the family. Empowering the role of the family in our society is something badly needed nowadays because the first fortress for countering the impact of the media is family. In some cases, religious schools are not effective enough to instill a good understanding of religion to protect individuals from the negative impacts of media. ${ }^{28}$ Together with upgrading education and empowering families, the health factor is also important. Not only physical health but more important is mental health.

The third important factor is the factor of face to face method of learning Islam. Among the imams strongly encourages the more intensive learning Islam through face to face method

\footnotetext{
${ }^{26}$ Interview with Malaysian Imam, (December 2018).

${ }^{27}$ Interview with Ust. Ulul Azmi, (December 5, 2018).

${ }^{28}$ Interview with Ust. Hasri, (December 25, 2018).
} 
with the syeikh. Because learning through the media is very prone to raise misconceptions. ${ }^{29}$ This, at the same time, encourages the da'is and religious leaders to adjust and wisely remind his congregation of the negative impact of media as the usage of any media belongs to individual rights.

The fourth is the engagement factor between religious leaders and society. As it is reminded by one of Malaysian imam:

So, what is needed ... For me, what needs to be emphasized is surau itself, the surau programs themselves, to be closer to the community. If possible, there are various programs in Surau. If possible, the program that we feel is normal is what we feel is more severe, for example like visiting a surau. We have made it. We know that our society is sick, so we come to see them. sometimes the case looks small but for society, it's good to deal. ${ }^{30}$

Last but not least is the vision of the country's leader. In this context, Ushama argues that "The most important thing is the vision of the leadership of your particular nation. If the leadership has a proper vision for the future of a nation, then it may be very helpful. In the sense that the vision must be Islamically recognized." 31

\section{Concluding Remarks: Maqāṣid-Based Media Ethics for the Fragmented Religious Authority}

The ethics, when it comes to media, somehow creates substantial contradictory as media naturally is never been valuefree. The existence of media as an industry cannot be separated from the many interests surrounding it. Indeed, from its very first establishment, media has already been attached to some particular

\footnotetext{
${ }^{29}$ Interview with Ust. Muhammad Khairun Nizam, (December 5, 2018).

${ }^{30}$ Interview with Malaysian imam, (December 2018).

31 Interview with Ushama, (December 2018).
} 
interests, be it of the stakeholders, authorities, or the capital owners. Besides being a neutral tool to do good things, media has been used to propagate, provoke, or to construct opinion that pleases only particular actors. Many writings on media ethics by the media scholars at this point I believe are self-critics to media actors to bring back media to its very pure nature. In the era of disruption of religious disinformation spread through what socalled "new media," media ethics becomes an urgent term to be revisited and re-actualized.

In media studies, the term media ethics mostly refers to the ethics of the workers of different kinds of media and its contents. In the Indonesian context, there are legal instruments have been produced to make sure the implementation of media ethics, among them: (1) Law No. 33 of 2009 concerning Film; (2) Law No. 36 of 1999 concerning Telecommunication; (3) Law No. 40 of 1999 concerning Press; (4) Law No. 19 of 2002 concerning Copyright; (5) Law No. 23 of 2002 concerning Child Protection; (6) Law No. 32 of 2002 concerning Broadcasting.

The above-established laws, guidelines, and code of ethics regarding media life in Indonesia however still not enough to increase people's awareness to act according to ethics. At this point, I do agree with Chang who argues, from the communication studies perspective, that parents play as key actors in the process of instilling communication ethical values because parents' example becomes an example for children in the family. This educational initiative is mainly in the hands of parents which then complemented by teachers or educators who play an important role in continuing ethical values education that has been long pioneered by parents. ${ }^{32}$ Here I see the importance of some sort of ethical education initiatives for different elements in society in general and in a family in particular, from parents, children, and family as a whole.

\footnotetext{
32 William Chang, Etika Dan Etiket Komunikasi: Rahasia, Sadap-Menyadap, Ujaran Kebencian, Hoax (Yogyakarta: Kanisius, 2018), 9.
} 
It also needs the importance of becoming an active information recipient and critical user of technology, or Chang preferred to call it as "agent of censorship". ${ }^{33}$ According to him, it can be done through "Program Pembinaan Hati Nurani" (Conscience Development Program). He argues that a pure and responsible conscience will help someone to make good decisions and take the right actions. If that is not taken seriously inside different environments of our lives; families, schools, places of worship, workplaces, and communities, then the world will experience a prolonged crisis of value and make people go with no clear direction. $^{34}$

This crisis, in my opinion, will even be worse in a liquid society that we are experiencing now. A postmodern society that is known for its fluid, not easy to stop, the extraordinary mobility of information exchange, of human interaction, of economic transaction, even more, of socio-religious experiences and expressions. A society with a renewed conception of emancipation, individuality, time/space, work, community; ${ }^{35}$ a society that lives under conditions of prolonged and apparently incurable uncertainty' and loss of sensitivity. ${ }^{36} \mathrm{~A}$ desert-like life, where all ways, signs and orientation points are constantly shifting. Our footprints disappear in the first desert wind, yet they bear witness to our existence and thus serve as orientation signs on our social journeys in the increasingly fragmented, contingent, and unstable postmodern reality. ${ }^{37}$ In the context of our discussion on media ethics and people's conscious development, the conditions of our

\footnotetext{
33 Ibid., 90.

34 Ibid., 156-161.

35 Zygmunt Bauman, Liquid Modernity (New York, NY: John Wiley \& Sons, 2013), accessed February 29, 2020, http://nbn-resolving.de/urn:nbn:de:101:1201412204670.

36 Zygmunt Bauman and Leonidas Donskis, Moral Blindness: The Loss of Sensitivity in Liquid Modernity. (Hoboken: Wiley, 2014), accessed February 29, 2020, http://grail.eblib.com.au/patron/FullRecord.aspx?p=1181435.

37 Jiří Přibáň, Liquid Society and Its Law (London; New York: Routledge, 2016), accessed February 29, 2020, https://www.taylorfrancis.com/books/e/9781315592534.
} 
liquid society as previously described will definitely be a fundamental obstacle against the ethic and the formation of a healthy conscience. ${ }^{38}$

In general, the current fragmentation of religious authority is actually a process that must be passed by Muslim communities towards a better media life. In Indonesian socio-religious context, there really is nothing to worry about in this process, because religion will eventually guide the community to determine their best direction. However, great efforts need to be made to improve many aspects of society, mainly their (religious) knowledge and the re-actualization of religious norms. That includes the reorientation of our paradigm toward many concepts in Islam which are related to ulama- ness, Islamic sciences, and even divinity.

To make those happen, there are some real steps that might be done in the future: first, in the realm of education, I see the need for media literacy to be included in various levels of education in Indonesia, from elementary to college levels. This literacy is expected to be integrated into the curriculum and inserted into certain materials in subjects taught at different levels of education. ICT subjects should also include materials on how students able to use the media wisely, sort out and choose nutritious information, and make optimal use of ICT products to increase knowledge in various fields, especially in religion. This actually requires the integration between curricula in schools and improving the quality of the educators.

Second, in the context of media regulation, I propose what I call maquasid-based media ethics as an answer to the challenges of the emergence of the i-Ulama. Here I need to emphasize that the iUlama does not refer only as of the emergence of new generations of ulama who are integrated into the world of the internet but also, borrowing the term Nasaruddin Umar, "the impersonal ulama." The i-Ulama are the Muslim scholars who are not only limited by the limitations that define the ulama in terms of physical existence.

${ }^{38}$ William Chang, Etika Dan Etiket Komunikasi..., 161. 
The scholars, whose religious authority is judged from substantive qualities as ulama and are not merely justified by the aesthetic qualities of their outside appearances. The nature of their existence which is not limited to physical forms consequently makes their religious authority goes beyond geographical boundaries even across material constraints. Accordingly, the media regulation that must be raised should not be a regulation that only regulates physical activities in the media, but rather regulates the substantive values of living in media life. The maquasid-based media ethics in this matter, in my humble opinion, is the best example of such regulation. A media regulation based on the benefit of a human being. The universal values adopted by maqūsid sharìah are very useful to be the basis of a media law that touches on substantial aspects of society; the protection of religion (din), life (nafs), intellect ('aq), lineage (nas), property (maa)..$^{39}$

Despite of the long debate regarding the meaning and elements of the maquasid sharìah, ${ }^{40}$ here I will only focus the discussion on the contextualization of the above al-Shatibi's five elements of maqūșid shariah into media ethics discourse. To begin with, it is worth noting here that "opinions on the construction of a universal code of ethics, that is referring to all media and endorsed by all media professionals, are somehow divided." 41 The proposed formula of maqāsid-based media ethics here is also actually not intended to provide an ethical standard that could be universally accepted, but rather to provide an alternative point of view of an ethical construction of society's interaction with media.

To construct a media ethic means to form a set of ethical standards that should apply to all media and media professionals. The first thing to understand here is how the media works?

\footnotetext{
39 Abu Ishaq al-Shatibi, Al-Muñäfaqāt (Saudi Arabia: Dar Ibn 'Affān li al-Nashr wa at-Tawzì , 1997).

40 Hisham Abu Sa'id Azhar, Maqāshid Al-Sharìah 'inda Imām al-Haramain wa Atharubā Fi al-Tașarrufāt al-Māliyah (Riyadh: Maktabah al-Rushd, 2010).

${ }^{41}$ Paweł Czarnecki, "Codes of Media Ethics," Humanum: Międrynarodowe Studia Spoteczno-Humanistyczne, 27, no. 4 (2017).
} 
Because ethics is very much attached to human's actions, so we need to understand who are the actors behind media production. According to Sirikit Syah, a media activist, practitioner, and scholar at the same time, there are at least five actors behind a media production, particularly in a television industry: owner, news director, producer, and advertiser. Each of these elements has a different but interrelated role and authority in determining what and how to produce and distribute the information in the media industry. More importantly, they are "not simply mindless cogs in a media machine." 42 The clear challenge is to make them aware of and obey ethics.

The second thing to do is to understand what is meant by each of the five elements of maquasid shari’ah. Al-Raysuni wrote a particular book explaining each element of maquasid sharìab as it is understood from Quran and Hadith. He mentioned some important points. First, the protection of religion (bif $z$ al-din). According to Shatibi, it can be realized by carrying out three important concepts: Imàn, Islàm, Iḥsàn. Second, the protection of life (bifz al-nafs) which means that the Islamic teachings are intended for maintaining the origin of human beings through the reproductive process to maintain their survival by fulfilling their basic needs like food, water, residence, etc. Third, the protection of property (hifz al-māt) that means to maintain property through a legal process of ownership and develop it through any means that do not violate sharia. And last the protection of intellect (bifz al'aq) means that God created the rules in this universe for saving human's minds from any things that might disturb it. ${ }^{43}$

Following understanding the original context of maqāsid shar'ah as previously explained, we would like to contextualize it into the realm of media to find ethical standards that should apply

42 David Croteau and William Hoynes, Media/Society: Industries, Images, and Audiences (Chicago: Sage Publications, 2014).

43 Ahmad Ar-Raysuni, Nazariyyāt al-Maqāshid 'inda al-Imām al-Shätibì (Virginia: The International Institute of Islamic Thought, 1995), 177. 
to all media and media professionals to form a maquasid-based media ethics. The most important thing about preserving Islam is maintaining the understanding of Muslims towards their religion based on the basic teachings. in the context of media, this means that the media must play a role in helping the community to provide filtered information about Islamic teachings and educate them to be able to choose and sort valid information about religion and, more importantly, encourage people to contextualize those religious teachings into everyday life. This can happen only if media workers and professionals do have good competencies not only in media production and journalism technicalities but competencies in imān, Isläm, and ihsān.

Furthermore, protecting religion in the context of media means maintaining inter-religious relations in society. Because the media should not only be leaning on one religion, instead, it is supposed to be a shared forum for all religions to be able to express these diverse religious values. The actors behind media production, at this point, have an important duty to be able to provide balanced information regarding different religions and not to vilify or favor one religion over another. Also, they should pay more attention to the profile of the resource person who will be presented to talk about religion, to the authoritative references to the basics of religion

The next point is the protection of life, which means mainly saving the origins of human beings and maintaining their existence. In the context of media, protecting life means making the media a means of information, promotion, and education of a physically and psychologically healthy life. This includes protecting the life of many living things in this world, from plants to animals, from river to jungle, from biological to social environments. Protecting life in a media life also includes protecting human being's online and offline existence; their personal information, classified state documents, and individual records and reputations. 
Another point of maquasid is the protection of lineage which emphasizes the importance of protecting our current family relation to ensure the goodness for the next generation. As it can be understood from the Islamic marriage law, one of its goals is to ensure that we have healthy relationships between families so that the future of our children and grandchildren will also be good and even better. In the context of media, this means that the media must play its role in informing, promoting, educating society on the importance of family relationships that are built on religion and social norms. at the same time, the media also plays the same role in the dangers of free sex, underage marriages, and many other social diseases.

The protection of the property is one of the sharia's objective. In the context of media, protecting wealth means fortifying the media for various digital-based theft attempts. This includes building a solid cybersecurity system as well as intellectual property. The media must be able to be a tool that helps maintain that kind of property and plays its supervisory role.

\section{Bibliography}

Al-Shātibī, Abū Ishāà. Al-Muwāafaqāt. Saudi Arabia: Dar Ibn 'Affān li al-Nashr wa at-Tawz $\overrightarrow{1}, 1997$.

Ar-Raysuni, Ahmad. Nazariyyāt al-Maquāsid 'inda al-Imām al-Shätibi. Virginia: The International Institute of Islamic Thought, 1995.

Azhar, Hisham Abu Sa'id. Maqāșid Al-Shariah 'inda Imām alHaramain wa Atharubā Fi al-Tașarrufät al-Mäliyah. Riyadh: Maktabah al-Rushd, 2010.

Bauman, Zygmunt and Donskis, Leonidas. Moral Blindness: The Loss of Sensitivity in Liquid Modernity. Hoboken: Wiley, 2014.

Bauman, Zygmunt. Liquid Modernity. New York: John Wiley \& Sons, 2013. 
Chang, William. Etika Dan Etiket Komunikasi: Rahasia, SadapMenyadap, Ujaran Kebencian, Hoax. Yogyakarta: Kanisius, 2018.

Croteau, David and Hoynes, William. Media/Society: Industries, Images, and Audiences. Chicago: Sage Publications, 2014.

Czarnecki, Pawel. "Codes of Media Ethics." Humanum: Międzynarodowe Studia Spoleczno-Humanistyczne, (27, no. 4, 2017).

Deleuze, Gilles and Guattari, Félix. A Thousand Plateaus: Capitalism and Schizophrenia. Minneapolis: University of Minnesota Press, 1987.

Feng, Robin Chee Ming and Chen, James. "Shopping for God: Media and Religion In Singapore" in Francis Khek Gee Lim (ed.), Mediating Piety. London: Brill, 2010.

Hoover, Stewart M. The Media and Religious Authority. Pennsylvania: Pennsylvania State University Press, 2017.

Kluver, Randolph and Cheong, Pauline Hope. "Technological Modernization, the Internet, and Religion in Singapore." Journal of Computer-Mediated Communication, (12, no. 3, April 2007).

Kusrin, Zuliza Mohd, et al. "Legal Provisions and Restrictions on The Propagation of Non-Islamic Religions Among Muslims in Malaysia." Kajian Malaysia (31, no. 2 2013).

Povera, Adib. "Internet Users in Malaysia up from 2.5mil in 2006 to 24.5mil in 2017." New Straits Times (accessed December 26, 2018).

https://www.nst.com.my/news/nation/2018/02/331284/i nternet-users-malaysia-25mil-2006-245mil-2017.

Přibáň, Jiř́i. Liquid Society and Its Law. London: Routledge, 2016.

Rahman, Azimaton Abdul, et al."Muslims in Cyberspace: Exploring Factors Influencing Online Religious Engagements in Malaysia." Media Asia (42, no. 1-2, April 3, 2015). 
Samuri, Mohd Al Adib and Hopkins, Peter. "Voices of Islamic Authorities: Friday Khutba in Malaysian Mosques." Islam and Christian-Muslim Relations, (28, no. 1, January 2, 2017).

Teoh, Shannon. "Malaysian Preacher Arrested for Sedition after Criticizing Johor Sultan's Decree against Muslim-Only Launderette." The Straits Times, (accessed December 27, 2018). https://www.straitstimes.com/asia/seasia/malaysian-preacher-apologises-over-commentscriticising-johor-sultans-decree-against.

\section{Interview}

Interview with Leyaket Ali, (November 9, 2018).

Interview with Nasarudin Umar, (December 2018).

Interview with Musta'in Mashud, (December 1, 2018).

Interview with Ushama, (December 2018).

Interview with Osman Bakar, (December 2018).

Interview with Ust. Rahmani, (December 4, 2018).

Interview with Ust. Ulul Azmi, (December 5, 2018).

Interview with Ust. Muhammad Khairun Nizam, (December 5, 2018).

Interview with Ust. Hasri, (December 25, 2018). 